\title{
Evaluating Corporate Identity in the Office of Production Business Group in Bangkok through Automotive Business and Real Estate Business
}

\author{
Thana Sirijansawang ${ }^{1} \&$ Prapatpong Upala ${ }^{1}$ \\ ${ }^{1}$ Faculty of Architecture, King Mongkut's Institute of Technology Ladkrabang (KMITL), Bangkok, Thailand \\ Correspondence: Thana Sirijansawang. Multidisciplinary Design Research, Faculty of Architecture, King Mongkut's \\ Institute of Technology Ladkrabang, Bangkok, Thailand. Tel: 6692-2586-685. E-mail: a_thana2000@yahoo.com
}

Received: July 13, 2017

doi:10.5539/ass.v13n9p174
Accepted: July 27, $2017 \quad$ Online Published: August 25, 2017

URL: https://doi.org/10.5539/ass.v13n9p174

\begin{abstract}
The objective of this research is to (1) evaluate the differences of physical factors and (2) evaluate the level of Building users' perception of the physical factors in the office which convey the meaning of Corporate Identity between the automotive business and the real estate business. The samples chosen for this research include 10 automotive business offices and real estate offices located in Bangkok area with a total number of 324 persons, using questionnaire to collect relevant data; using Likert Scale to evaluate the internal environment in the office; using t-test / ANOVA to analyze perceptual level data and differences in 8 physical factors which reflect the corporate identity under this research, i.e. (1) Colors in decoration; (2) Lighting in decoration; (3) Furniture style; (4) Decorative style; (5) The shape of space; (6) Continuity of space; (7) Wall decoration and graphic works and (8) Material in decoration. Based on the results of the research, it was found that there were physical factors which reflected the corporate identity of the organization and affected the perception level of those who were building users at a high level. The said 4 physical factors consisted of (1) Colors in decoration; (2) Interior decorative style; (3) Lighting in decoration, and lastly (4) Material in decoration. However, the individual characteristics of building users such as gender, age, and duration of work also affected the recognition of corporate identity significantly.
\end{abstract}

Keywords: Corporate Identity, Corporate visual Identity, Perception, Physical factor

\section{Introduction}

The rapidly changing world is quickly forcing every business operation to adapt itself to cope with the strong competition in line with the modification. The automotive industry is vital to the overall economic growth in the development of the country. Thailand as the primary manufacturing base of Asian region (Industrial Master Plan, 2012) and the world's $15^{\text {th }}$ largest automotive production capacity. As such, it has attracted world's leading car brands to focus on carrying out their marketing and expanding their production capacity in Thailand. (Yongpisanphob, 2016). In addition to the production competition for the competency of responding to the demand of consumers both locally and internationally, businesses entrepreneurs also need to focus on the importance of competition to differentiate their image, service and product quality which will create the degree of trust and confidence to consumers as well as respond to changing trend in consumers' tastes and behavior in the future. (Tafesse, Narui \& Korneliussen, 2014). Such concept of Corporate Identity in the physical environment is essential in the organizational management and operation of the automotive industry/business, not only reflecting the personality and uniqueness of the office but also creates a difference in image and indicates credibility which are the crucial factors to determine customers' purchasing decisions. (Sirijansaaswang, Upala, 2017, a)

In the Asian region, the real estate sector was considered as one of the important industries of the economy as a whole. The social and economic change including infrastructure development plan of the public sector including the factor of change in the way of life of people who live and work in cities, and the more distinct lifestyle patterns. In the business, the use of Corporate Identity strategy is not only reflecting a concept of promoting taste value of price-conscious consumers which influences their purchasing decision (Glickman, 2014) on products and services of that particular organization, but is also important to build organizational credibility and effectiveness toward the physical environment in the office (Grey \& Balmer, 1998). Such change, therefore, is a driving force 
to the business entrepreneurs in real estate industry to adapt themselves to respond to consumers' behavior and lifestyle in the future.

The usefulness of the use of Corporate Identity concept in office design can promote confidence, which affects positive behavior and attitude towards products and services (Daniel \& Sandu, 2015) and also helps to expand new customer base while maintaining existing customer base as well as increasing sales volume. As such, it creates creditability and consumer's confidence (Teimouri, Fanae, Jenab, Khoury \& Moslehpour, 2016). Lots of budgets invested reflects an effort to create a brand and corporate image which is the key strategy (Tafesse, Narui \& Korneliussen, 2014) of competitive advantage in the business world.

Therefore, the concept of Corporate Identity is necessary to develop the understanding for all employees in the organization to have a common understanding of work and corporate governance (Hashim, Haque \& Hasim, 2015). The use of Corporate Identity concept to design physical factor in an office is, thus, the key element which reflects the Corporate Identity of an organization with its particular pattern, affecting attitudes and behaviors of corporate practice in the organization and conveys the image (Sahachaisaeree, 2012), both positively and negatively, subject to the quality of visual physical factor in the office, such as factor of using lighting and color in decoration; furniture style; decorative style; shape of space; wall decoration and graphic works as well as the use of materials. (Sthienrapapayut \& Sahachaisaeree, 2010).

The objective of this research is, therefore, to evaluate the differences in physical factors and also to evaluate the perception level of building users toward the physical factors in the office which reflects Corporate Identity between the automotive business group and the real estate business group. The conclusion of the research demonstrates the differences in conveying Corporate Identity and the perception level of the Building users towards the physical factors in the office as necessary information and guidelines for designing physical factors in the office, using Corporate Identity design concept as the strategic instrument.

The structure of this article is divided into six main sections as follows: (1) The importance of Corporate Identity concept toward business operation and perception of building users; (2) Groups of Corporate Identity concept and related research; variables physical factors which can reflect Corporate Identity in the environment; (3) The conceptual framework of the research; (4) Research procedures and approaches; (5) Summary and result of data analysis and lastly, (6) Conclusion and recommendations to the research through the presentation of guidelines for designing physical factors which reflects Corporate Identity and its impact on the perception level of building user group.

\section{Literature Review}

\subsection{Business Base on Corporate Identity}

Under any business operation, it is essential for a company to develop the difference in Corporate Identity in terms of product, quality, value and the awareness of consumer's loyalty to product and services provided (Durmaz \& Yasar, 2016); the situation of business competition outside the organization as well as communicates with employees in the organization to understand the importance of Corporate Identity which can motivate and encourage employees' working performance in the organization. (Kashive \& Khanna, 2017); working behavior which plays a vital role in the business operation and influences the level of creditability and differentiation of products and services directly to consumers. (Drabjerdi, Arabi, \& Haghighikhah, 2016). As such, Corporate Identity contributes to marketing and organizational management benefits towards high competition in the same business/industry. A good image in particular of a product and organization will create consumer's confidence in the situation of competition and data comparison (Tafesse, Narui \& Korneliussen, 2014) of the product and service. A good image can also reflect the lifestyle as well as the social status of the target group and consumers (Van, Chi, T., Chi, V. \& Quang, 2016).

\subsection{Corporate Visual identity \& environment}

The importance of Corporate Visual Identity concept affects corporate governance in the organization. It is one of the factors which reflects the unique character of the organization's behavior of work procedure and organizational management (Iyamabo, Owolawi, Otubanjo \& Balogun, 2013). Corporate Visual Identity demonstrates through some physical factors which importantly link corporate and office environments together for people outside the organization and individuals concerned in the organization (Olmedo-Cifuentes \& Martinez-Leon, 2014). Physical factor in the environment is important, and it is visible through and conveys the essential characteristic of Corporate Identity in a workplace, such as the use of color, the use of lighting, furniture style, decorative styles, the use of materials and graphic works. These physical factors constitute and create unique atmosphere and style which reflect the Identity of that organization (Sahachaisaeree, 2012; 
Sirijansawang \& Upala, 2017, a; and Iyamabo, Owolawi, Otubanjo \& Balogun, 2013). For example, the use of color is an important part of creating the uniqueness and creditability of the organization in compliance (Jalil, Yunus \& Said, 2012) with their opinions on the issues of the use of color or type of font as the key factor which can create significant meaning the unique characteristic of the organization as well as the utilization of a graphic works which creates an integrated view of an organization with unique personality; the design of graphic works on the wall and the Corporate's logo (Grey \& Balmer, 1998) are also important factors to develop the awareness of people inside and outside the organization on the unique characteristic of the organization to the environment in the office. Factor of continuity of space and layout plan is also another key physical factor which reflects the organization's overall management characteristic and overall atmosphere (Sahachaisaeree, 2012) which points out factors in various aspects, such as the use of material in decoration and the shape of the space (Sirijansawang \& Upala, 2017, b) can affect the perception of building users towards Corporate Identity under the work environment.

\subsection{Corporate Visual Identity Support Behavior \& Perception}

The Corporate Visual Identity concept in the physical environment is an important conclusion showing the level of market value. It reflects the work behavior of the group of people in the organization today and in the future to that organization (Van, Chi, T., Chi, V. \& Quang, 2016). The level of Corporate Identity perception including work behavior and employee satisfaction levels in that organization depends upon the quality level of conveying the physical factor related to Corporate Identity in that particular environment and can predict employees' behavior and guideline of the work very well (Kashive \& Khanna, 2017) while (Kamarulzaman, Saleh, Hashim, Hashim \& Abdul-Ghani, 2011) and (Poursafar, Rodrigues \& Devi, 2017) points out the critical issue of specific characteristic of physical environment affecting the employees' work behavior, quality of work produced, same as (Sahachaisaeree, 2011) the issue of psychological interpretation in the physical environment and the creation of good atmosphere in that working space and can also create positive attitude for the building users. (Hashim, Haque \& Hasim, 2015), as well as the pattern of behavior and efficiency of utilizing indoor space for building users. In addition to physical environment variables individual characteristic variable is the factor which affects perception of individual in the area, such as gender, age, education level, work experience of building users and in many researchers, efforts have been made to examine the effect of employees' perceptions of Corporate Identity (Kashive \& Khanna, 2017) and the behavior of building users.

\subsection{Physical Factors in the working environment}

A good working environment can respond to and support the performance of the work of building users including the quality of the work and satisfaction level of building users. The physical factors within the office premises were, therefore, important which could directly affect the building users, such as factor in decorative style, the use of color and light in decoration, furniture style, appropriate temperature level, decorative material and the overall atmosphere in the office premises. (Ali El-Zeiny, 2012) Such physical factors could both positively and negatively affect the work of the building user group. However, it also depended upon the quality and composition of the environment, (Yazdanfar, Heidari \& Aghajari,2015) such as the type of lighting, as well as the use of color in decoration and inconsistent ceiling heights could affect the satisfaction level of working and the clarity of use in the space, as well as the perceptions of building users toward that particular environment (Savavibool, Gatersleben \& Moorapun, 2016).

\section{Research Framework}

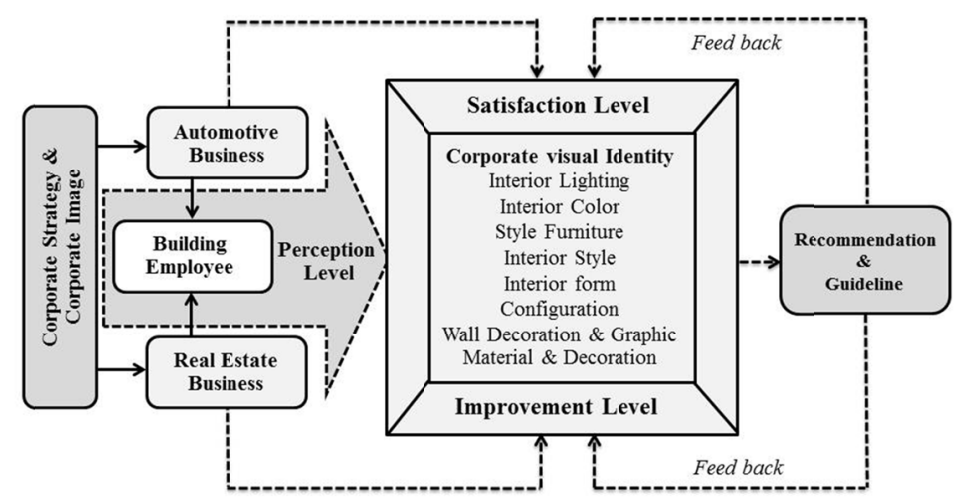

Figure 1. Conceptual Frame work 
Research Framework aims to study the level of perception of physical factors which characterize Corporate Identity of building users in the office through the evaluation of 8 physical factors between the automotive business office and the real estate office including satisfaction level and the need for physical improvement in the office. To know the difference between physical factors that can convey the Corporate Identity of building users, the conclusion will be a guideline to design further physical factors in the office using Corporate Identity concept as shown in Figure 1.

\section{Research Design}

The study used Survey Research methodology to evaluate the physical environment, reflecting Corporate Identity in the office under the following steps:

\subsection{Step 1: Reliability and Accuracy of the Testing Tools}

The questionnaire to conduct the evaluation of the environment and physical factors in the office is divided into 4 parts, consisting of, Part (1) Individual characteristic data; Part (2) Evaluate the Corporate Identity under the overall physical condition in the office; Part (3) Evaluate physical factors which reflect Corporate Identity in 8 different physical elements, i.e. (1) Lighting in decoration; (2) Color in Decoration; (3) Furniture style; (4) Interior Decorative Style; (5) Shape of space; (6) Continuity of space; (7) Wall decoration and graphic works and (8) Material used in decoration. And Part (4) Evaluate the satisfaction level and what should be improved on the physical condition which reflects Corporate Identity in the office, using Likert Scale, Questionnaires and Evaluation tools were inspected by the experts in the field of office design and professional instructor in the field of interior architectural design. The result of the assessment showed the confidence value level at 0.896-0.964

\subsection{Step 2: Field Sample Selection in the Research}

Sample selection process is based on two phases of selection, i.e. Step 1, carry out Simple Random Sampling from the business classification registration database, Stock Exchange of Thailand. (Stock Exchange of Thailand, 2017) To obtain samples from 8 Industrial groups. Based on the selection, the automotive business group and the real estate business group were selected. The second stage of the research process then builds on the purposive sampling methodology, having the criteria of selection for the essential characteristic of such sample group as follows: (1) Being an office of physical condition design in the office, based on Corporate Identity concept; (2) Having indoor space and work space of not less than 500 square meters, and (3) Having at least 50 full-time staff working in the office in the Bangkok area.

\subsection{Step 3: Field Survey for the Research}

A selection of 5 automotive business offices as the samples group under this research was made, consisting of HONDA, MINI, BMW, NISSAN and LUXUS and five real estate business offices were also selected namely, SANSIRI, AREEYA, LPN, MK, and LH. Such sample groups were based on the ranking of sales in Thailand (Report on domestic car sales, 2015); and (Real estate sales report, 2015) The researcher carried out such field survey to obtain the required data based on sample size of 324 employees who worked on a full-time basis as shown in Figure 2.

\begin{tabular}{|l|c|c|c|}
\hline \multicolumn{1}{|c|}{ Brand } & Office Physical & $\begin{array}{c}\text { Income/2015 } \\
\text { (Thousand ) }\end{array}$ & Rank \\
\hline 1) HONDA & Building separate & 112,178 & 3 \\
\hline 2) NISSAN & Office Building & 51,193 & 5 \\
\hline 3) BMW & Building separate & 8,768 & 11 \\
\hline 4) MINI & Building separate & 921 & 17 \\
\hline 5) LEXUS & Building separate & 834 & - \\
\hline
\end{tabular}

\begin{tabular}{|l|c|c|c|}
\hline \multicolumn{1}{|c|}{ Brand } & Office Physical & $\begin{array}{c}\text { Income/2015 } \\
\text { (Thousand })\end{array}$ & Rank \\
\hline 1) SANSIRI & Office Building & 6,970 & 2 \\
\hline 2) LAND\&HOUSE & Office Building & 6,328 & 3 \\
\hline 3) LPN. & Building separate & 2,197 & 7 \\
\hline 4) AREEYA & Building separate & 784 & 11 \\
\hline 5) MK. & Building separate & 3,749 & - \\
\hline
\end{tabular}

Source: http://www.headlightmag.com/salesreport_total2015/ and http:/ www./terrabkk.com/news/

Figure 2. Comparison of business sales and physical data of research samples.

\subsection{Step 4: Data Analysis}

Data obtained from the survey was taken for data analysis, using a statistic t-test and ANOVA as the tools for such data analysis to illustrate the comparison of the mean between independent variables, i.e. the 8 physical factors which reflected Corporate Identity between dependent variables, consisting of perception level of building users toward the physical factors in the office premises in the 2 business groups, processed by SPSS for Windows and using a statistical significance level of $.05 \%$ 


\section{Result and Discussions}

To understand this research, the fundamental structure, and procedure for data analysis under this research was set out in 4 parts as follows: Part (1) Analyzing Corporate Identity level as a whole in the office, using t-test statistics for such analysis; Part (2) Analyzing the perception level towards physical factors which conveys Corporate Identity of building user group; Part (3) Analyzing level of satisfaction toward physical factors and Part (4) Analyzing level of physical improvement using t-test / ANOVA statistics for data analysis.

The research questionnaire consisted of 324 samples with a similar proportion of data collection, divided into 161 samples of automotive offices, accounted for $49.4 \%$ and 163 samples of real estate offices, accounted for $50.6 \%$. Based on the data collected, it was found that (1) Gender: the number of males is more than female in automotive office while the number of females has more proportion than males in real estate offices; (2) Age: it was found that in the motor vehicle office, there were building user group whose ages were in the range of 21-30 years of age which were more than the others age range, accounted for $50.9 \%$, the same as it was found in the real estate office with the proportion of building user group in the range of 21-30 years of age, more than any other group, accounted for $43.6 \%$; (3) Role and Duty: it was found that the two largest business groups were the operational staff, accounted for $88.2 \%$ of the automotive office, which was $73 \%$ more than the real estate offices while the supervisory staff, accounted for $20.9 \%$ in the actual estate office, which was $11.2 \%$ more than the automotive office and (4) Working time: it was found that $68.3 \%$ were the building user group of automotive office who had working time ranged from 1-5 years, more than the real estate office group, accounted for $45.4 \%$, having staff of supervisory and managerial level in the estate office more than the automotive office group as shown in Table 1.

Table 1. Sample Characteristic

\begin{tabular}{cccccc}
\hline Variables & & Automotive $(\mathrm{n}=161)$ & Real Estate $(\mathrm{n}=163)$ & Percent & Total \\
\hline Gender & Male & $87(54.0 \%)$ & $73(44.8 \%)$ & 49.4 & 160 \\
& Female & $74(46.0 \%)$ & $90(55.2 \%)$ & 50.6 & 164 \\
Age & $21-30$ years & $82(50.9 \%)$ & $71(43.6)$ & 47.2 & 153 \\
& 31-40 years & $53(32.9 \%)$ & $61(37.4)$ & 35.2 & 114 \\
& $41-50$ years & $26(16.1 \%)$ & $31(19.0)$ & 17.6 & 57 \\
Time & $1-5$ years & $110(68.3)$ & $74(45.4)$ & 56.8 & 184 \\
& 6-10 years & $36(22.4 \%)$ & $44(27.0)$ & 24.7 & 80 \\
& $<10$ years & $15(9.30 \%)$ & $126(27.6)$ & 18.5 & 60 \\
Responsibility & $142(88.2)$ & $34(20.9)$ & 82.7 & 268 \\
& Employees & $18(11.2 \%)$ & $3(1.84)$ & 16.0 & 52 \\
& Head to Division & $1(0.6 \%)$ & & 1.2 & 4 \\
\hline
\end{tabular}

\subsection{Overall Corporate Identity Level in the office between Business Group}

Based on data analysis on the overall perception of Corporate Identity between business groups, using t-test statistics analysis, it was found that the building user group in the automotive office responded to the overall evaluation in the office more than the other group in the real estate office. There were statistically significant differences at the level of .05 ( $\left.<<.05=.000^{*}\right)$ which reflected the physical differences in the automotive office and had made the building user group better aware of corporate identity than the other group in the real estate office who seemed to have less recognition on the Corporate Identity because of limited physical existence in the office in terms of spaces and description of work which affected the Corporate Identity level in the office as shown in Table 2 .

Table 2. Table showing the mean and standard deviation on the perception of physical factors that reflected Corporate Identity among Businesses Groups in this Research

\begin{tabular}{|c|c|c|c|c|c|c|c|c|}
\hline \multirow{2}{*}{ Dependent variables } & \multicolumn{3}{|c|}{ Automotive $(\mathrm{N}=161)$} & \multicolumn{3}{|c|}{ Real estate $(\mathrm{N}=163)$} & \multirow{2}{*}{$t$-value } & \multirow{2}{*}{$p$} \\
\hline & $\overline{\mathrm{x}}$ & S.D. & Priority & $\overline{\mathrm{x}}$ & S.D. & Priority & & \\
\hline Over all Identity Office & 3.68 & .629 & - & 3.30 & .915 & - & $4.335^{*}$ & $.000 *$ \\
\hline Interior Lighting & 3.68 & .724 & 3 & 3.37 & .856 & 3 & $3.454^{*}$ & $.031 *$ \\
\hline
\end{tabular}




\begin{tabular}{cccccccccc}
\hline Interior Color & 3.80 & .688 & 1 & 3.42 & .932 & 2 & $4.168^{*}$ & $.000^{*}$ \\
Style Furniture & 3.60 & .719 & 6 & 3.29 & .878 & 6 & $3.538^{*}$ & $.017^{*}$ \\
Interior Style & 3.72 & .701 & 2 & 3.45 & 1.088 & 1 & $2.650^{*}$ & $.000^{*}$ \\
Interior form & 3.60 & .688 & 6 & 3.24 & .854 & 9 & $4.231^{*}$ & $.010^{*}$ \\
Configuration & 3.61 & .682 & 5 & 3.28 & .825 & 7 & 3.922 & .105 \\
Wall Decoration \& Graphic & 3.55 & .722 & 8 & 3.27 & 1.059 & 8 & $2.785^{*}$ & $.000^{*}$ \\
Material \& Decoration & 3.64 & .678 & 4 & 3.35 & 1.039 & 4 & $3.054^{*}$ & $.000^{*}$ \\
Satisfaction level & 3.42 & .671 & 9 & 3.14 & .863 & 10 & $3.202^{*}$ & $.003^{*}$ \\
Improvement level & 3.19 & .824 & 10 & 3.34 & .926 & 5 & -1.533 & .110 \\
\hline
\end{tabular}

$* \mathrm{p}<.05$ is the level of significance

\subsection{Perception of Physical Factors which affect Corporate Identity among Business Groups}

Based on the data analysis on the level of physical perception factors which conveyed Corporate Identity among business groups, it was found that the automotive office group had higher mean than the real estate office in all physical factors and was very prominent in the following three factors (1) The average for Factor of using color in decoration was 3.80 whereas the mean of the real estate office was 3.42; (2) The average for Factor of Decorative Style was 3.72 whereas it was 3.45 for the actual estate office; and (3) The mean for Factor of using lighting in decoration in automotive office was 3.68 while the average of the real estate office was 3.64 and was greater than the average of the actual estate office which was 3.35 ; $(5)$ The mean of Factor on continuity of space was 3.61 in the automotive offices and 3.28 in the real estate office; (6) Shape of Space and (7) Furniture Style was at the level of 3.60 in the motor vehicle office which was greater than the mean of the real estate office at the level of 3.24. (8) The average of Factor of Wall Decoration and Graphic Works in the automotive office was at the level of 3.42, greater than the mean of the real estate office at the level of 3.27; (9) The average for Factor of Satisfaction was at the level of 3.42 in automotive office, greater than the mean in the real estate at 3.14 and lastly, (10) The average for Factor of Physical Improvement was 3.10, less than the average in the automotive office at 3.34 all of these reflected the level of physical improvement required in the office. As such, the Physical Factors from 1 to 3 are the strengths which reflect the Corporate Identity of the organization and the mean for the perception of building users was high because the factor of colors reflected the Corporate Identity which helped to build users connected to the organization well under the physical environment of under office decoration which would affect the second factor in the style of decoration due to the unique decorative style which met and promoted the characteristics of automotive sales and corporate personality. The third factor concerning the use of lighting in the decoration of automotive sales environment, the lighting factor was an important part to promote the prominent and beauty to the car and atmosphere in the exhibition area including continuity in the work of building users.

Table 3. Comparative table of physical satisfaction in offices between business groups.

\begin{tabular}{ccccccc}
\hline \multirow{2}{*}{ Dependent variables } & \multicolumn{3}{c}{ Automotive } & \multicolumn{3}{c}{ Real estate } \\
\cline { 2 - 7 } & $\overline{\mathrm{x}}$ & S.D. & Priority & $\overline{\mathrm{x}}$ & \multicolumn{1}{c}{ S.D. } & Priority \\
\hline Interior Lighting & 3.43 & .804 & 3 & 3.25 & .906 & 2 \\
Interior Color & 3.46 & .806 & 2 & 3.28 & .996 & 1 \\
Style Furniture & 3.40 & .809 & 5 & 3.12 & .947 & 5 \\
Interior Style & 3.47 & .888 & 1 & 3.16 & 1.139 & 4 \\
Interior form & 3.35 & .801 & 6 & 3.09 & .847 & 7 \\
Configuration & 3.47 & .766 & 1 & 3.20 & .930 & 3 \\
Wall Decoration \& Graphic & 3.33 & .858 & 8 & 2.93 & 1.098 & 8 \\
Material \& Decoration & 3.42 & .834 & 4 & 3.10 & 1.075 & 6 \\
\hline
\end{tabular}

$* \mathrm{p}<.05$ is the level of significance

\subsection{Satisfaction of the physical condition in an office among business groups}

The outcome of the comparative analysis toward satisfaction level on physical condition in the office showed that in the automotive office, the building users were more satisfied with the physical condition than the real 
estate office and was consistent with the data of physical improvement required at a low level in the automotive office while the level required for improvement was high in the real estate office as shown in Table 2. The data showed the difference in the satisfaction of the building user group towards the physical factors between the two businesses. The automotive offices had higher mean level than the real estate offices in every physical factor. There was a high level of satisfaction in 3 physical factors which included (1) Interior style of decoration and continuity of the space; (2) Color in the decoration; (3) Lighting in decoration. While real estate offices had a high level of satisfaction in 3 physical factors, i.e. (1) Colors in decoration and (2) Lighting in decoration and (3) Continuity of space, as shown in Table 3.

Table 4. Comparison table for environmental improvement in offices between business groups.

\begin{tabular}{ccccccc}
\hline \multirow{2}{*}{ Dependent variables } & \multicolumn{3}{c}{ Automotive } & \multicolumn{3}{c}{ Real estate } \\
\cline { 2 - 7 } & $\overline{\mathrm{x}}$ & S.D. & Priority & $\overline{\mathrm{x}}$ & S.D. & Priority \\
\hline Interior Lighting & 3.20 & .949 & 5 & 3.38 & 1.061 & 3 \\
Interior Color & 3.11 & .951 & 8 & 3.26 & 1.104 & 8 \\
Style Furniture & 3.21 & 1.002 & 4 & 3.37 & .994 & 4 \\
Interior Style & 3.11 & 1.036 & 8 & 3.34 & 1.194 & 5 \\
Interior form & 3.25 & .957 & 2 & 3.33 & 1.037 & 6 \\
Configuration & 3.18 & .995 & 6 & 3.27 & 1.007 & 7 \\
Wall Decoration \& Graphic & 3.27 & .982 & 1 & 3.40 & 1.109 & 1 \\
Material \& Decoration & 3.22 & 1.03 & 3 & 3.39 & 1.119 & 2 \\
\hline
\end{tabular}

${ }^{*} \mathrm{p}<.05$ is the level of significance

\subsection{Physical Improvement required in the Office among Business Groups}

The level of physical improvement required in the building users group in automotive office fall under the following three physical factors: (1) Wall Decoration and Graphic Works; (2) Shape of Space; (3) Material in decoration. While the mean required for improvement was high in the real estate office, (1) Wall Decoration and Graphic Works; (2) The material in decoration and (3) Lighting in decoration as shown in Table 4. Upon the analysis and consideration of the issues of required improvement from building users group, it reflected the inadequacy of the use of space, for example. If the automotive office made some improvements on the decorated wall, using material and the shape of space, to complete the improvement, such improvement would be an integral part of promoting the Corporate Identity to be in compliance with the use of space by automotive business very well while the 3 physical factors in the real estate office would focus on required improvement to promote the work and create atmosphere in the office. To better understand the data, the researcher analyzed the relationship between the unique characteristics of building users called primary variables, i.e. (1) gender, (2) age, (3) duration of work, and (4) the role of building users with the variables of Corporate Identity Perception, at the satisfaction level; the required physical improvement on the variables in this research.

\subsection{Perception of Corporate Identity in the office with gender variables}

Based on t-test data analysis, it was found that the level of physical perception factors reflecting Corporate Identity, the mean evaluated by males was greater than the average of females in every aspect of physical factor except (1) The use of lighting in decoration factor and (2) No difference was found in Factor of using color in decoration. The male's perception of Corporate Identity in the office was higher than those of the females, reflecting the environmental perception level in conveying a clearer meaning than the females as shown in Table 5.

Table 5. Table showing the mean and standard deviation for perceived physical factors that reflect organizational Identity and gender variables in the research

\begin{tabular}{|c|c|c|c|c|c|c|c|c|}
\hline \multirow{2}{*}{ Dependent variables } & \multicolumn{3}{|c|}{ Male $(\mathrm{N}=160)$} & \multicolumn{3}{|c|}{ Female $(\mathrm{N}=164)$} & \multirow{2}{*}{$t$-value } & \multirow{2}{*}{$p$} \\
\hline & $\overline{\mathrm{x}}$ & S.D. & Priority & $\overline{\mathrm{x}}$ & S.D. & Priority & & \\
\hline Over all Identity Office & 3.50 & .765 & - & 3.48 & .849 & - & $.256^{*}$ & $.041 *$ \\
\hline Interior Lighting & 3.51 & .754 & - & 3.54 & .855 & - & -.308 & .183 \\
\hline Interior Color & 3.62 & .796 & - & 3.58 & .882 & - & .623 & .064 \\
\hline Style Furniture & 3.49 & .725 & 4 & 3.40 & .898 & 3 & $.981 *$ & $.013 *$ \\
\hline
\end{tabular}




\begin{tabular}{cccccccccc}
\hline Interior Style & 3.64 & .844 & 1 & 3.54 & 1.00 & 1 & $.969^{*}$ & $.028^{*}$ \\
Interior form & 3.49 & .718 & 4 & 3.35 & .861 & 5 & $1.647^{*}$ & $.019^{*}$ \\
Configuration & 3.52 & .669 & 3 & 3.38 & .862 & 4 & $1.529^{*}$ & $.001^{*}$ \\
Wall Decoration \& Graphic & 3.41 & .827 & 5 & 3.40 & .999 & 3 & $.136^{*}$ & $.006^{*}$ \\
Material \& Decoration & 3.56 & .801 & 2 & 3.43 & .966 & 2 & $1.35^{*}$ & $.010^{*}$ \\
\hline
\end{tabular}

$* \mathrm{p}<.05$ is the level of significance

\subsection{Corporate Identity Perception in the office and age variables}

Based on ANOVA data Analysis, it was found that building user group had its requirement for physical improvement in the office. However, there were three different factors to consider i.e. (1) Lighting in decoration $\left(\mathrm{p}<.05=.013^{*}\right)$ (2) Color in Decoration $\left(\mathrm{p}<.05=.012^{*}\right)$ and (3) Interior style of decoration $\left(\mathrm{p}<.05=.024^{*}\right)$ as shown in Table 6. When these factors were taken to conduct a paired comparative analysis, it was found that the older age building users were more likely to perceive Corporate Identity than younger ones. Considering the difference of issues under these three factors, it was found that the decoration was the important issue which reflected the overall atmospheres in the office as shown in Table 7.

Table 6. The table was showing Comparative Analysis on improvement required for physical factor in the office with age variables

\begin{tabular}{|c|c|c|c|c|c|c|}
\hline Dependent Variables & & Sum of Squares & $\mathrm{df}$ & Mean Square & $\mathrm{F}$ & $p$ \\
\hline \multirow{3}{*}{ Interior Lighting } & Between Groups & 8.833 & 2 & 4.416 & 4.420 & $.013^{*}$ \\
\hline & Within Groups & 320.723 & 321 & .999 & & \\
\hline & Total & 329.556 & 323 & & & \\
\hline \multirow{3}{*}{ Interior Color } & Between Groups & 9.396 & 2 & 4.698 & 4.505 & $.012 *$ \\
\hline & Within Groups & 334.740 & 321 & 1.043 & & \\
\hline & Total & 334.136 & 323 & & & \\
\hline \multirow{3}{*}{ Interior Style } & Between Groups & 9.402 & 2 & 4.701 & 3.789 & $.024 *$ \\
\hline & Within Groups & 398.236 & 321 & 1.241 & & \\
\hline & Total & 407.639 & 323 & & & \\
\hline
\end{tabular}

$* p<.05$ is the level of significance

Table 7. Result of the paired comparative analysis on improvement required for physical factors in the office with age variables

\begin{tabular}{|c|c|c|c|c|c|}
\hline & Age & $\overline{\mathrm{x}}$ & $21-30$ years & $31-40$ years & $41-50$ years \\
\hline \multirow{4}{*}{$\begin{array}{l}\text { Interior } \\
\text { lighting }\end{array}$} & & & 3.19 & 3.25 & 3.64 \\
\hline & 21-30 years & 3.19 & - & -0.06 & $-0.45^{*}$ \\
\hline & $31-40$ years & 3.25 & & - & $-0.39 *$ \\
\hline & $41-50$ years & 3.64 & & & - \\
\hline \multirow{4}{*}{$\begin{array}{l}\text { Interior } \\
\text { Color }\end{array}$} & & & 3.05 & 3.21 & 3.52 \\
\hline & $21-30$ years & 3.05 & - & -0.16 & $-0.47 *$ \\
\hline & $31-40$ years & 3.21 & & - & -0.31 \\
\hline & $41-50$ years & 3.52 & & & - \\
\hline \multirow{4}{*}{$\begin{array}{l}\text { Interior } \\
\text { style }\end{array}$} & & & 3.13 & 3.18 & 3.59 \\
\hline & $21-30$ years & 3.13 & - & -0.05 & $-0.46^{*}$ \\
\hline & $31-40$ years & 3.18 & & - & $-0.41 *$ \\
\hline & $41-50$ years & 3.59 & & & - \\
\hline
\end{tabular}

$* \mathrm{p}<.05$ is the level of significance

\subsection{Perception of Corporate Identity in the office as a whole with duration of work variables}

Based on the data obtained from the analysis of the unique characteristics of building users during the period of work aspect, it was found that there was a significant statistical difference in the overall Corporate Identity at $(\mathrm{p}<.05=.032 *)$ as shown in Table 8 . Upon conducting a paired comparative analysis, it was found that the overall 
building user group in the office whose duration of work were in the range of 6-10 working years had higher response to the Corporate Identity than the group whose period of work was in the range of 1-5 working years and the group with duration of work was more than a decade, as shown in Table 9, indicated that a shorter or longer length of work could affect the perceptual perspective of people in the organization. Less duration of work might still not affect the emotion and understanding of the organization whereas a longer period of work might be familiar with the importance of loyalty to that particular organization.

Table 8. Table was showing Result of Variance Analysis to compare the difference of overall Corporate Identity in the office of building user group categorized by duration of work.

\begin{tabular}{ccccccc}
\hline Dependent Variables & & Sum of Squares & df & Mean Square & $\mathrm{F}$ & $p$ \\
\hline \multirow{3}{*}{ Over all Identity Office } & Between Groups & 4.489 & 2 & 2.244 & 3.492 & $.032^{*}$ \\
& Within Groups & 206.300 & 321 & .643 & & \\
& Total & 210.789 & 323 & & & \\
\hline
\end{tabular}

${ }^{*} \mathrm{p}<.05$ is the level of significance

Table 9. Result of paired comparative analysis on the level of the overall Corporate Identity in the office with the duration of work variables.

\begin{tabular}{ccccc}
\hline \multirow{2}{*}{ Work period } & \multirow{\mathrm{x}}{*}{} & $1-5$ years & $6-10$ years & $<10$ years \\
\cline { 3 - 5 } & & 3.52 & 3.58 & 3.25 \\
\hline $1-5$ years & 3.52 & - & -0.06 & $0.27^{*}$ \\
6-10 years & 3.58 & & - & $0.33^{*}$ \\
$<10$ years & 3.25 & & & - \\
\hline
\end{tabular}

$*_{p}<.05$ is the level of significance

\subsection{Level of physical satisfaction in the office with working period variable}

The data showing the differences in the level of satisfaction among the building users indicated a significant statistical difference in the factor of a style of interior decoration at the level of $\left(p<.05=.021^{*}\right)$ as shown in Table 10. Upon conducting the paired comparative analysis, it was found that the building user group whose duration of work was in the range of 6-10 working years had a higher satisfaction level than those whose period of work was in the range of 1-5 working years and the group whose duration of work was more than ten working years. Based on such conclusions on the above two issues, it indicated that during the average length of work or 6-10 working years, there was a clearer view and understanding on the implication of Corporate Identity in the office than other building user group as illustrated in Table 11.

Table 10. Table was showing Comparative Analysis result on differences in physical satisfaction and working period variables

\begin{tabular}{|c|c|c|c|c|c|c|}
\hline Dependent Variables & & Sum of Squares & $\mathrm{df}$ & Mean Square & $\mathrm{F}$ & $p$ \\
\hline \multirow{3}{*}{ Interior Style } & Between Groups & 8.205 & 2 & 4.102 & 3.914 & $.021 *$ \\
\hline & Within Groups & 336.413 & 321 & 1.048 & & \\
\hline & Total & 344.617 & 323 & & & \\
\hline
\end{tabular}

${ }^{*} \mathrm{p}<.05$ is the level of significance

Table 11. The Paired Comparative Analysis result of physical satisfaction and time variables.

\begin{tabular}{|c|c|c|c|c|}
\hline \multirow{2}{*}{ Work period } & \multirow{2}{*}{$\overline{\mathrm{x}}$} & $1-5$ years & $6-10$ years & $<10$ years \\
\hline & & 3.34 & 3.50 & 3.01 \\
\hline $1-5$ years & 3.34 & - & -0.16 & $0.33 *$ \\
\hline $6-10$ years & 3.50 & & - & $0.49^{*}$ \\
\hline$<10$ years & 3.01 & & & - \\
\hline
\end{tabular}

$* \mathrm{p}<.05$ is the level of significance 


\subsection{Physical improvement required in the office with working period variables}

Based on data analysis result on the difference in the physical improvement required by building user group, it showed that there was a significant statistical difference in the aspect of the factor of a style of interior decoration at the level of at the $\left(\mathrm{p}<.05=.019^{*}\right)$ as illustrated in Table 12. Upon conducting a Paired Comparative analysis, it was found that the building user group whose duration of work was more than ten working years expressed their views for the higher requirement to the physical improvement in terms of decoration aspect than those whose period of work was in the range of 1-5 working years and 6-10 working years respectively. In Table 1, the data showed that a significant amount of duration of action might create more perception toward people in the organization and required improvements which would reflect a greater awareness of the existence of the organization than the building user group with shorter duration of work.

Table 12. Table was showing the Comparative Analysis result on physical improvement required with the length of work variables

\begin{tabular}{ccccccc}
\hline Dependent Variables & & Sum of Squares & $\mathrm{df}$ & Mean Square & $\mathrm{F}$ & $p$ \\
\hline \multirow{3}{*}{ Interior Style } & Between Groups & 10.001 & 2 & 2.487 & 2.145 & $.019^{*}$ \\
& Within Groups & 379.638 & 321 & 1.195 & & \\
& Total & 407.639 & 323 & & & \\
\hline
\end{tabular}

$* \mathrm{p}<.05$ is the level of significance

Table 13. Paired Comparative Analysis result of physical improvement required for factors which reflected Corporate Identity with the duration of work variables

\begin{tabular}{cccccc}
\hline & Time & $\overline{\mathrm{x}}$ & $1-5$ years & $6-10$ years & $<10$ years \\
\hline \multirow{2}{*}{ Interior } & & & 3.14 & 3.15 & 3.60 \\
style & 1-5 years & 3.14 & - & -0.01 & $-0.46^{*}$ \\
& 6-10 years & 3.15 & & - & $-0.45^{*}$ \\
& $<10$ years & 3.60 & & - \\
\hline
\end{tabular}

${ }^{*} \mathrm{p}<.05$ is the level of significance

Therefore, the shorter and longer duration of work were both affected the emotional views of people in the organization. Less duration of work might not very much emotionally be affected the corporate identity while the longer period of work might emotionally affect the business loyalty.

\subsection{Perception Level of Corporate Identity in the office with the role variables}

Based on the result of data obtained from the analysis of building user group's role in the perception of Corporate Identity in the office, it was found that there were different levels of perception toward 2 physical factors, i.e. (1) Interior Decorative Style, having the statistical significance at the level of $\left(p<.05=.029^{*}\right)$; (2) Material in decoration, at the level of $(\mathrm{p}<.05=.042 *)$ as shown in Table 14. Upon conducting the paired comparative analysis, it was found that the management level had a higher level of Corporate Identity perception which was different from the operational and the supervisory staff levels. In consideration of the mean of the first two groups, the role of the management in administrating the overall operation of the organization and the longer duration of work in the office somehow resulted in a significant amount of understanding of the organizational entity and Corporate Identity as illustrated in Table 15.

Table 14. Table was showing Comparative Analysis result of the differences in factors which reflected corporate identity with the role variables

\begin{tabular}{ccccccc}
\hline Dependent Variables & & Sum of Squares & df & Mean Square & F & $p$ \\
\hline \multirow{2}{*}{ Interior Style } & Between Groups & 6.074 & 2 & 3.037 & 3.577 & $.029 *$ \\
& Within Groups & 272.491 & 321 & .849 & & \\
& Total & 278.564 & 323 & & & \\
& Between Groups & 4.988 & 2 & 2.494 & 3.190 & $.042 *$ \\
Material \& Decoration & Within Groups & 250.972 & 321 & .782 & & \\
& Total & 255.960 & 323 & & & \\
& & & &
\end{tabular}

$* \mathrm{p}<.05$ is the level of significance 
Table 15. The result of Paired Comparative Analysis with the perception factors which reflect corporate identity with the position variables

\begin{tabular}{|c|c|c|c|c|c|}
\hline \multicolumn{2}{|c|}{ Responsibility } & $\overline{\mathrm{x}}$ & Employees & Head to Division & Chief Executive \\
\hline \multirow{4}{*}{$\begin{array}{c}\text { Interior } \\
\text { Style }\end{array}$} & & & 3.64 & 3.33 & 2.95 \\
\hline & Employees & 3.64 & - & $0.31 *$ & 0.69 \\
\hline & Head to Division & 3.33 & & - & $0.38 *$ \\
\hline & Chief Executive & 2.95 & & & - \\
\hline \multirow{4}{*}{$\begin{array}{l}\text { Material \& } \\
\text { Decoration }\end{array}$} & & & 3.55 & 3.27 & 2.85 \\
\hline & Employees & 3.55 & - & $0.28 *$ & 0.70 \\
\hline & Head to Division & 3.27 & & - & $0.42 *$ \\
\hline & Chief Executive & 2.85 & & & - \\
\hline
\end{tabular}

${ }^{*} \mathrm{p}<.05$ is the level of significance

\subsection{The level of physical satisfaction in the office with role variables}

The data indicated the difference in the role of building user group toward the physical satisfaction level in the office under 2 factors, i.e. (1) Interior decorative style which had the level of significance at $\left(p<.05=.046^{*}\right)$ and (2) Material in decoration at the level of $(\mathrm{p}<.05=.024 *)$ as shown in Table 16. Upon conducting the paired data, it was found that the operational and supervisory levels had the high level of satisfaction which was different from the management level group whose mean was at the low level for both physical factors. The cause was due to the sharing of the workspace, and it was the group with similar age range, so, it influenced the level of satisfaction view to the same direction as shown in Table 17.

Table 16. Table showing the variance analysis to compare differences in satisfaction toward the factors reflecting Corporate Identity with the role variables

\begin{tabular}{ccccccc}
\hline Dependent Variables & & Sum of Squares & df & Mean Square & F & Sig. \\
\hline \multirow{2}{*}{ Interior Style } & Between Groups & 6.530 & 2 & 3.265 & 3.100 & $.046 *$ \\
& Within Groups & 338.087 & 321 & 1.053 & & \\
& Total & 334.617 & 323 & & 3.780 & $.024 *$ \\
Material \& Decoration & Between Groups & 7.068 & 2 & 3.53 & \\
& Within Groups & 300.104 & 321 & .935 & & \\
& Total & 307.173 & 323 & & & \\
& & & & &
\end{tabular}

${ }^{*} \mathrm{p}<.05$ is the level of significance

Table 17. Paired Comparative Analysis results on the level of satisfaction with the factors, conveying the Corporate Identity with the role variables

\begin{tabular}{|c|c|c|c|c|c|}
\hline \multicolumn{2}{|c|}{ Responsibility } & $\overline{\mathrm{x}}$ & Employees & Head to Division & Chief Executive \\
\hline \multirow{4}{*}{$\begin{array}{c}\text { Interior } \\
\text { Style }\end{array}$} & & & 3.38 & 3.03 & 2.25 \\
\hline & Employees & 3.38 & - & $0.35^{*}$ & 1.13 \\
\hline & Head to Division & 3.03 & & - & 0.78 \\
\hline & Chief Executive & 2.25 & & & - \\
\hline \multirow{4}{*}{$\begin{array}{l}\text { Material \& } \\
\text { Decoration }\end{array}$} & & & 3.32 & 3.00 & 2.50 \\
\hline & Employees & 3.32 & - & $0.32 *$ & 0.82 \\
\hline & Head to Division & 3.00 & & - & 0.50 \\
\hline & Chief Executive & 2.50 & & & - \\
\hline
\end{tabular}

$* \mathrm{p}<.05$ is the level of significance

\subsection{Physical Improvement required in the office with the Role Variables}

The analysis result of the building user group with the physical improvement required in the office based on the role variables of the building users indicated that the supervisory and management staff group had a significantly higher mean than those of the operational staff group in every respect of physical factors as shown in Table 18. The analysis found that there was a difference in all physical factors except for the factor of furniture style and factor of wall decoration and graphic works because, in general, the style of furniture in the office was mainly designed for general purpose in the office, but it was emphasized in the aesthetics and the use of furniture together 
with the usage of both furniture style and wall decoration including graphic works in some important spaces, such as reception is, meeting room, where customers could access to, so, there was no significant difference in employees' perception of the function of the above issue as shown in Table 19.

Table 18. Table was showing Comparative Analysis for improvement required to factors which reflect the Corporate Identity with the role variables

\begin{tabular}{|c|c|c|c|c|}
\hline Dependent Variables & & $(\mathrm{N}=324)$ & $\overline{\mathrm{x}}$ & S.D. \\
\hline \multirow{3}{*}{ Interior Lighting } & Employees & 268 & 3.23 & 1.02 \\
\hline & Head to Division & 52 & 3.53 & .89 \\
\hline & Chief Executive & 4 & 4.25 & .95 \\
\hline \multirow{3}{*}{ Interior Color } & Employees & 268 & 3.12 & 1.03 \\
\hline & Head to Division & 52 & 3.51 & .98 \\
\hline & Chief Executive & 4 & 3.50 & 1.00 \\
\hline \multirow[t]{4}{*}{ Style Furniture } & Employees & 268 & 3.23 & 1.00 \\
\hline & Head to Division & 52 & 3.59 & .91 \\
\hline & Chief Executive & 4 & 3.50 & 1.00 \\
\hline & Employees & 268 & 3.15 & 1.12 \\
\hline \multirow[t]{3}{*}{ Interior Style } & Head to Division & 52 & 3.59 & 1.07 \\
\hline & Chief Executive & 4 & 3.75 & .95 \\
\hline & Employees & 268 & 3.22 & .99 \\
\hline \multirow[t]{3}{*}{ Interior Form } & Head to Division & 52 & 3.65 & .96 \\
\hline & Chief Executive & 4 & 3.50 & 1.00 \\
\hline & Employees & 268 & 3.16 & 1.00 \\
\hline \multirow[t]{2}{*}{ Configuration } & Head to Division & 52 & 3.57 & .93 \\
\hline & Chief Executive & 4 & 3.25 & .50 \\
\hline \multirow[t]{4}{*}{ Wall Decoration } & Employees & 268 & 3.29 & 1.05 \\
\hline & Head to Division & 52 & 3.57 & 1.01 \\
\hline & Chief Executive & 4 & 3.75 & .95 \\
\hline & Employees & 268 & 3.23 & 1.07 \\
\hline \multirow[t]{2}{*}{ Material \& Decoration } & Head to Division & 52 & 3.65 & 1.02 \\
\hline & Chief Executive & 4 & 4.00 & 1.15 \\
\hline
\end{tabular}

Table 19. Comparative analysis table of changes needed to factor in organizational identities and role variables

\begin{tabular}{|c|c|c|c|c|c|c|}
\hline Dependent Variables & & Sum of Squares & df & Mean Square & $\mathrm{F}$ & $p$ \\
\hline \multirow{3}{*}{ Interior Lighting } & Between Groups & 7.692 & 2 & 3.846 & 3.836 & $.023 *$ \\
\hline & Within Groups & 321.863 & 321 & 1.003 & & \\
\hline & Total & 329.556 & 323 & & & \\
\hline \multirow{3}{*}{ Interior Color } & Between Groups & 7.218 & 2 & 3.609 & 3.914 & $.033 *$ \\
\hline & Within Groups & 336.917 & 321 & 1.050 & & \\
\hline & Total & 344.136 & 323 & & & \\
\hline \multirow[t]{3}{*}{ Style Furniture } & Between Groups & 5.969 & 2 & 2.985 & 3.021 & .050 \\
\hline & Within Groups & 317.176 & 321 & .988 & & \\
\hline & Total & 323.145 & 323 & & & \\
\hline \multirow{3}{*}{ Interior Style } & Between Groups & 8.205 & 2 & 4.102 & 3.888 & $.021 *$ \\
\hline & Within Groups & 336.413 & 321 & 1.048 & & \\
\hline & Total & 344.617 & 323 & & & \\
\hline \multirow{3}{*}{ Interior Form } & Between Groups & 8.219 & 2 & 4.110 & 4.210 & $.021 *$ \\
\hline & Within Groups & 313.336 & 321 & .976 & & \\
\hline & Total & 331.556 & 323 & & & \\
\hline \multirow{3}{*}{ Configuration } & Between Groups & 7.420 & 2 & 3.710 & 3.766 & $.019 *$ \\
\hline & Within Groups & 316.218 & 321 & .985 & & \\
\hline & Total & 323.639 & 323 & & & \\
\hline
\end{tabular}




\begin{tabular}{ccccccc}
\hline Wall Decoration & Between Groups & 4.231 & 2 & 2.116 & 1.936 & .146 \\
& Within Groups & 350.741 & 321 & 1.093 & & \\
& Total & 354.972 & 323 & & 4.241 & $.019 *$ \\
& Between Groups & 9.710 & 2 & 4.855 & & \\
Material \& Decoration & Within Groups & 367.426 & 321 & 1.145 & & \\
& Total & 377.136 & 323 & & \\
\hline
\end{tabular}

$* \mathrm{p}<.05$ is the level of significance

Apart from the use of the environmental design which reflected Corporate Identity in the office, one of the important issues to be considered in addition to the aesthetics of the meaning conveyed, was the effectiveness in exploiting employers' capabilities in the organization. It was, therefore, essential to improve and remedy the weak points to create efficiencies in implying Corporate Identity and building user group in the organization.

\section{Conclusions and Recommendation}

The conclusion is that the overall picture of automotive business office can better reflect and imply Corporate Identity than the real estate business office and there are physical factors to convey the meaning of the strength of Corporate Identity in automotive business under 3 physical factors, i.e. (1) Color in Decoration; (2) Interior decorative style and (3) Lighting in decoration while the real estate business office emphasizes the importance of (1) Interior decorative style; (2) color in decoration, and (3) Lighting in decoration. It is concluded as the 3 physical factors of strength which convey the meaning of Corporate Identity., the proportion is more or less depending on the specific management of particular organization in compliance with the level of satisfaction of both groups of building user whereas the level of physical improvement required which is considered as the weakness of both businesses and needed to be improved to better understand Corporate Identity as well, including the 2 physical factors i.e. (1) Wall decoration and graphic works; (2) Material in decoration and (3) Requirement to improve the factor of shape of space in the automotive office and factor of using lighting in decoration in the real estate business.

On the issue of individual characteristic of the building user group under this research, i.e. the variables of gender, age, duration of work and role, it is a part which affects the level of Corporate Identity Perception in the office. Male variables are more pronounced in evaluating patterns which signify the Corporate Identity than females. The analysis also indicates that most males evaluate factors which contribute to the view as a whole, while females have their evaluation of patterns in particular. For the variation of age, the older age group will have a better sense of organization entity and requires physical improvement to generate effectiveness to the work while the younger age group will better understand and accept the Corporate Identity. The variables on duration of work in the range of 6-10 working years is a group of people who understand the overall pictures, they are more satisfied with the style of decoration than the group of 1-5 working years and the group of more than 10 working years, while the group who has duration of work more than 10 working years require physical improvements on the style of decoration. As such, the longer duration of work somehow affects a greater sense of corporate integrity and loyalty to the organization while the role variables at the executive and supervisory levels require more significant physical improvement than those who are at the operational level because the perspective on the organization's management still require physical improvement for more effect on the actual practice.

The recommendation of this research aims to guide the development of physical factors in the office where it can signify a clearer Corporate Identity which will affect the perception of building users. The automotive business office has four physical factors that should be improved, i.e. (1) Continuity of Space; (2) Shape of Space. Both physical factors can be enhanced by defining an Open Space Plan which can connect employees' workplace areas together with the creation of the shape of space inconsistent with the style of interior decoration; (3) Furniture style should be developed to have particular characteristic incompatible with the interior decoration style and some spaces can be focused for specific use purpose, and (4) Wall Decoration and Graphic Works in which improvement can be made by considering additional wall decoration which can connect with specific characteristic of company's logo, such as color pattern including graphic works, such as font styles, and so on.

In the real estate business group, there are 4 physical factors to be improved i.e. (1) Furniture style which can be developed into a specific model in some spaces and the choice of models that conform to interior guidelines and usage; (2) Continuity of Space which can be improved by configuring the layout of the area in the office for continuity by providing Open space for usage and the perception of building users; (3) Wall Decoration and Graphic Works which can be improved by adding graphical themes to decorative walls, such as the font type that can convey the identity of organization or wall decoration using the corporate logo color to connect with the unique characteristic in the office and (4) Shape of Space which can be modified from the interior decoration in 
some areas to create a distinctive point and can connect to specific characteristics in that particular organization, such as the reception space, meeting room space, and so on.

\section{References}

Ali El-Zeiny R.M. (2012). The Interior Design of Workplace and its Impact on Employees' Performance: A Case Study of the Private Sector Corporations in Egypt. Procedia - Social and Behavioral Sciences, 746-756. https://doi.org/10.1016/j.sbspro.2012.02.145

Daniel, S., \& Sandu, M. C. (2015). Reputation - An important element for automotive industry Profit?. Procedia - Economics and Finance, 32, 1035-1041. https://doi.org/10.1016/S2212-5671(15)01565-8

Drabjerdi, J. J., Arabi, M., \& Haghighikhah, M. (2016). Identifying the effective factors on brand equity from consumers perspective using Aaker model: A case of Tehran dairy Products. International Journal of Business and Management, 11(4), 265-273. http://dx.doi.org/10.5539/ijbm.v11n4p265

Durmaz, Y., \& Yasar, H. V. (2016). Brand and brand strategies. International Business Research, 9(5), 48-56. http://dx.doi.org/10.5539/ibr.v9n5p48

Glickman, E. (2014). An introduction to real estate finance. New York: Academic Press of New York University (pp. 399-418). Retrieved from https://doi.org/10.1016/B978-0-12-378626-5.00014-0

Gray, E. R., \& Balmer, J. M. T. (1998). Managing corporate image and corporate reputation. Long Range Planning, 31(5), 695-702. http://doi.org/10.1016/S0024-6301(98)00074-0

Hashim, N., Haque, A., \& Hasim, N. H. (2015). Moderating effect of income on the service environment and customers' behavioral intention. Procedia - Social and Behavioral Sciences, 170, 27, 596-604. https://doi.org/10.1016/j.sbspro.2015.01.061

Iyamabo, J., Owolawi, S., Otubanjo, O., \& Balogun, T. (2013), Corporate Identity: Identifying dominant elements in CI models. Journal of Management Research, 5(3), 28-43. http://dx.doi.org/10.2139/ssrn.2237498

Jalil, N. A., Yunus, R. M., \& Said, N. S. (2012). Environmental colour impact upon human behaviour: A review. Procedia - Social and Behavioral Sciences, 35, 54-62. https://doi.org/10.1016/j.sbspro.2012.02.062

Kamarulzaman, N., Saleh, A. A., Hashim, S. Z., Hashim, H., \& Abdul-Ghani, A. A. (2011). An overview of the influence of physical office environments towards employees. Procedia - Engineering, 20, 262-268. https://doi.org/10.1016/j.proeng.2011.11.164

Kashive, N., \& Khanna, V. T. (2017). Building employee brand equity to influence organization attractiveness and firm performance. International Journal of Business and Management, 12(2), 207-219. http://dx.doi.org/10.5539/ijbm.v12n2p207

Olmedo-Cifuentes, I., \& Martinez-Leon, I. M. (2014). Influence of management style on employee views of corporate reputation. Application to audit firms. Business Research Quarterly, 17(4), 223-241. http://doi.org/10.1016/j.brq.2013.08.001

Poursafar, Z., Rodrigues, L. L. R, \& Devi, R. (2017). Personality assessments in architects' offices: An empirical investigation of the relationship between personality types, forms and productivity in office interior. Modern Applied Science, 11(1), 235-241. http://dx.doi.org/10.5539/mas.v11n1p235

Real estate sales report, (2015). Retrieved from http:// www.terrabkk.com/news/

Report on domestic car sales, (2015). Retrieved from http://www.headlightmag.com/salesreport_total

Sahachaisaeree, N. (2012). Environmental simulation and behavioral response as means of enquiry in multidisciplinary design research procedure. Procedia - Social and Behavioral Sciences, 36, 35-50. https://doi.org/10.1016/j.sbspro.2012.03.005

Savavibool, N., Gatersleben, B., \& Moorapun, C. (2016). The Effects of Colour in Work environment: A Systematic Review. Environment-Behavior Proceeding Journal, 1(4). http://dx.doi.org/10.21834/e-bpj.v1i4.167

Sirijansawang, T., \& Upala, P. (2017,a). Evaluating corporate identity in the offices of advertising businesses through building users and design professionals. Proceedings of the International Symposium on Social Sciences and Management, ISSSM 2017 (pp. 789-803). Sapporo. Hokkaido: Higher Education Forum.

Sirijansawang, T., \& Upala, P. (2017b). Understanding corporate identity in the office of automotive business in Bangkok through building users and design professionals. Environment - Behaviour Proceedings Journal, 2(5), 493-505. http://dx.doi.org/10.21834/e-bpj.v2i5.628 
Sthienrapapayut, T., \& Sahachaisaeree, N. (2010). Corporate strategy as design orientation of spatial function and environmental identity: a case of Kasikorn Bank's branch office in Bangkok. Procedia - Social and Behavioral Sciences, 5, 1294-1300. https://doi.org/10.1016/j.sbspro.2010.07.278

Tafesse, W., Narui, J., \& Korneliussen, T. (2014). Branding goals and strategies at international auto shows. International Journal of Marketing Studies, 6(4), 23-34. http://dx.doi.org/10.5539/ijms.v6n4p23.

Teimouri, H., Fanae, N., Jenab, K., Khoury, S., \& Moslehpour, S. (2016). Studying the relationship between brand personality and customer loyalty: A case study of Samsung mobile phone. International Journal of Business and Management, 11(2), 1-10. http://dx.doi.org/10.5539/ijbm.v11n2p1

Thailand Automotive Institute. (2016, December 24). Master plan for automotive industry 2012-2016. Retrieved December 24, 2016, from http://www.thaiauto.or.th/2012/th/research/research-detail.asp?rsh_id=39

The Stock Exchange in Thailand. (2017). Retrieved from https://www.set.or.th/th/regulations/simplified_regulations/industry_sector_p1.html

Van, N. T., Chi, T. T. H., Chi, V. T. M. \& Quang, N. V. (2016). The relationship between customer-based corporate reputation and customer citizenship behavior: The case in Vietnam. International Journal of Business and Management, 11(9), 298-309. http://dx.doi.org/10.5539/ijbm.v11n9p298

Yazdanfar S.A., AkbarHeidarib A. \& Aghajaric N. (2015). Comparison of Architects' and Non-Architects' Perception of Place. Procedia - Social and Behavioral Sciences. Volume 170, 27 January 2015, Pages 690-699. https://doi.org/10.1016/j.sbspro.2015.01.071

Yongpisanphob, W. (2016, July). Automotive industry analysis in Thailand 2016-2018. Retrieved from https://www.krungsri.com/bank/getmedia/e6a3eaff-a3e9-4618-90be-bd964eac9d5b/IO_Automobile_2016_ TH.aspx

\section{Copyrights}

Copyright for this article is retained by the author(s), with first publication rights granted to the journal.

This is an open-access article distributed under the terms and conditions of the Creative Commons Attribution license (http://creativecommons.org/licenses/by/4.0/). 